\title{
FITOTERAPIA
}

Fitoterapia 75 (2004) 480-493

www.elsevier.com/locate/fitote

\section{Proteolytic properties of Funastrum clausum latex}

\author{
Susana R. Morcelle*, Néstor O. Caffini, Nora Priolo \\ Laboratorio de Investigación de Proteínas Vegetales (LIPROVE), \\ Departamento de Ciencias Biológicas, Facultad de Ciencias Exactas, \\ Universidad Nacional de La Plata, C.C. 711, B1900AVW, La Plata, Argentina
}

Received 23 January 2004; accepted 14 April 2004

\begin{abstract}
As part of a screening of latex endopeptidases from plants growing in Argentina, the presence of proteolytic activity in the latex of Funastrum clausum stems is reported. The proteases present in the crude extract showed the main characteristics of the cysteine proteolytic class, i.e. optimum $\mathrm{pH}$ at alkaline range, isoelectric point (pI) higher than 9.0, and inhibition of proteolytic activity by thiol blocking reagents. A remarkable thermal stability was also evident in the crude extract. Endosterolytic preference tried on $p$-nitrophenyl esters of $N$ - $\alpha$-carbobenzoxy-L-amino acids was higher for the alanine, asparagine and tyrosine derivatives. Preliminary peptidase purification by two-step ionic exchange showed the presence of two proteolytic fractions with molecular masses of approximately $24.0 \mathrm{kDa}$ according to SDS-PAGE.

(c) 2004 Elsevier B.V. All rights reserved.
\end{abstract}

Keywords: Funastrum clausum; Latex; Thiol proteases

\section{Introduction}

Latex is a milky fluid composed by a liquid serum holding, in suspension or in solution, a complex mixture of constituents. It may contain a variety of cellular components, like nuclei, mitochondria, ribosome-like particles, and lysosome analogues. Agglomerative low density materials, such as various enzymes, terpenes,

\footnotetext{
*Corresponding author.

E-mail address: morcelle@biol.unlp.edu.ar (S.R. Morcelle).
} 
alkaloids, vitamins, carbohydrates, lipids and free amino acids have been identified among the components. Latex has been reported to occur in 12000 plant species belonging to 900 genera. In a given family, the fact that not all genera are latex bearing complicates the definition of a role for latex in plants [1]. The presence of certain enzymes in latex vacuoles like chitinases and proteases suggests that it may help plants defenses against pathogens, parasites and herbivores by attacking the invader once the plant cell is lysed [2].

Besides the significant physiological roles played by endopeptidases, their commercial applications are of utmost importance, since they are one of the three largest groups of industrial enzymes, accounting for approximately $60 \%$ of the total worldwide sale of enzymes. Use of proteases in development of environmentally friendly technologies include leather treatment and several bioremediation processes [3], as well as their application in pharmaceutical industry for preparation of medicines such as ointments for debridement of wounds, and their assistance in the hydrolysis of large polypeptides in smaller peptides and aminoacids, facilitating the digestion and absorption of proteins [4].

A common feature that can be found in the latex of the Asclepiadaceae (also known as milkweed family, since these plants ooze a sticky, white latex when cut) is the presence of proteolytic activity. The study of the proteolytic characteristics of latex of Funastrum clausum is reported in this paper as part of a project on systematic screening of regional plant endopeptidases carried out in our laboratory. The species is widely spread from USA to Argentina, and used in popular medicine to kill screw-worm larvae in human flesh by application of a poultice of the leaves, as well as its latex is used to remove warts [5].

\section{Experimental}

\subsection{Abbreviations used}

AMPSO, 3-[(1,1-dimethyl-2-hydroxyethyl)amino]-2-hydroxy-propanesulfonic acid; BSA, Bovine Serum Albumin; CAPS, 3-(cyclohexylamino)-1-propanesulfonic acid; CBZ, carbobenzoxy; DEAE-Sepharose, diethylaminoethyl-Sepharose; DTT, dithiothreitol; E-64, trans-epoxysuccinyl-L-leucylamido-(4-guanidino)butane; EDTA, ethylendiaminetetraacetic acid; IEF, Isoelectric focusing; MOPS, 3-( $N$-morpholino) propanesulfonic acid; PMSF, phenylmethylsulfonyl fluoride; SDS, sodium dodecyl sulfate; SP-Sepharose, sulfopropyl-Sepharose; TAPS, $N$-tris(hydroxymethyl)methyl3-aminopropanesulfonic acid; TCA, trichloroacetic acid.

\subsection{Chemicals}

Casein (Hammarsten type) was obtained from Research Organics Inc., Cleveland, Ohio. AMPSO, CAPS, cysteine, DTT, E-64, EDTA, iodoacetic acid, MOPS, $p$ nitrophenyl esters of $N$ - $\alpha$-carbobenzoxy-L-amino acids, pepstatine A, PMSF, TAPS, Tris, glycine isoelectric point markers (IEF MIX 3.6-9.3), and Biolyte 3-10 carrier ampholytes were purchased from Sigma Chemical Company, St. Louis. Coomassie 
Brilliant Blue R-250, acrylamide, bisacrylamide and low molecular weight markers were obtained from Bio-Rad, Hercules, California. DEAE-Sepharose Fast Flow, SPSepharose Fast Flow, and Pharmalyte 3-10 were purchased from Pharmacia Biotech, Uppsala. All other chemicals were obtained from commercial sources and were of the highest purity available.

\subsection{Plant material}

F. clausum (Jacq.) Schlechter [Latin synonym: Sarcostemma clausum (Jacq.) Roem. and Schult.] (Asclepiadaceae), stems obtained from plants grown in Rosario, province of Santa Fe, Argentina (Argentinean folk names: tasi, doca, English common name: white twinevine). The plant is a vine, with leaves narrowly linear to broadly elliptic and white to greenish cream flowers [6]. Voucher specimen (UNR 1492) is deposited at the UNR herbarium, Facultad de Ciencias Agrarias, Universidad Nacional de Rosario, Argentina.

\subsection{Crude enzyme extract preparation}

Latex, obtained by superficial incisions of stems in late summer, was collected on $0.1 \mathrm{M}$ phosphate buffer ( $\mathrm{pH}$ 7.5) containing $5 \mathrm{mM}$ EDTA and cysteine, in order to avoid phenoloxidase activity and oxidation, respectively. This suspension was first centrifuged at $16000 \times g$ for $30 \mathrm{~min}$ at $4{ }^{\circ} \mathrm{C}$ in order to discard gums and other insoluble materials, and the supernatant was ultracentrifuged at $100000 \times g$ for 60 min at $4{ }^{\circ} \mathrm{C}$. The resulting supernatant containing soluble proteins was called 'crude extract' fractionated and conserved at $-20{ }^{\circ} \mathrm{C}$ for further studies.

\subsection{Proteolytic activity determination}

Casein was used as non-specific substrate for proteolytic activity determination of the crude extract and in the preliminary purified fractions when possible. The reaction mixture contained $0.1 \mathrm{ml}$ of crude extract and $1.1 \mathrm{ml}$ of $1 \%$ casein with 12 $\mathrm{mM}$ cysteine in a $0.1 \mathrm{M}$ Tris- $\mathrm{HCl}$ buffer $(\mathrm{pH} 8.0)$. The reaction was carried out at $45{ }^{\circ} \mathrm{C}$ and stopped $20 \mathrm{~min}$ later by adding $1.8 \mathrm{ml}$ of $5 \%$ trichloroacetic acid (TCA). Each test tube was centrifuged at $3000 \times g$ for $30 \mathrm{~min}$ and the absorbance of the supernatant was measured at $280 \mathrm{~nm}$ [7]. One caseinolytic unit $\left(U_{\text {cas }}\right)$ was defined as the amount of protease that produces an increment of one absorbance unit per minute in the assay conditions [8].

During the purification steps, proteolytic assays were performed as follows. In the case of fractions eluted from the anionic exchange column, caseinolytic activity was determined as mentioned above. Due to its higher sensibility, azocasein was used to measure the proteolytic activity of those fractions obtained from the cationic exchange column [9]. For this determination, $0.25 \mathrm{ml}$ of $2 \%$ azocasein in $0.1 \mathrm{M}$ glycine- $\mathrm{NaOH}$ buffer ( $\mathrm{pH} 9.5$ ) containing $20 \mathrm{mM}$ cysteine was added to $0.15 \mathrm{ml}$ of enzyme sample and incubated at $45{ }^{\circ} \mathrm{C}$ for $30 \mathrm{~min}$. The reaction was stopped by adding $1 \mathrm{ml}$ of $10 \%$ TCA. After centrifugation at $4000 \times g$ for $15 \mathrm{~min}, 0.9 \mathrm{ml}$ of 
the supernatant obtained was added to $1 \mathrm{ml}$ of $1 \mathrm{M} \mathrm{NaOH}$, and the absorbance was measured at $440 \mathrm{~nm}$. In this case, one unit of proteolytic activity $\left(U_{\text {azocas }}\right)$ was defined as the amount of enzyme, which produced an absorbance increase of one unit per minute under the assay conditions.

\subsection{Protein and carbohydrate content determination}

Proteins present in the crude extract and in partial purified fractions were measured according to Bradford's method [10] using BSA as standard. The protein content of chromatography eluates was estimated by absorbance at $280 \mathrm{~nm}$ during separation.

Measurement of sugar content of the proteolytic extract was achieved according to Dubois [11] using glucose as standard.

\subsection{Optimum $\mathrm{pH}$}

Crude extract caseinolytic activity was measured at $45{ }^{\circ} \mathrm{C}$ using $10 \mathrm{mM}$ sodium salts of the following 'Good' buffers: MES, MOPS, TAPS, AMPSO and CAPS, in the $\mathrm{pH}$ range of $6.5-10.5$ [12].

\subsection{Heat stability}

For testing heat stability, crude extract was incubated at different temperatures ranging from 25 to $70{ }^{\circ} \mathrm{C}$ for $2,5,10,20,40,60$ and $120 \mathrm{~min}$. The reaction was stopped in ice-water and the residual caseinolytic activity was measured under standard assay conditions.

\subsection{Effect of inhibitors and activators}

To elucidate the mechanistic nature of crude extract proteolytic activity, a set of inhibitors for different types of proteases was proved [13]. The crude extract was preincubated for 10 and $30 \mathrm{~min}$ at room temperature in the presence of the following inhibitors: $30 \mathrm{mM}$ iodoacetate; $1 \mathrm{mM}$ PMSF; $0.1 \mathrm{mM} \mathrm{E-64}$; and $10 \mu \mathrm{M}$ pepstatine, in separate aliquots. In the case of PMSF, reversion was assayed by adding cysteine $12 \mathrm{mM}$ to the mixture. The remaining caseinolytic activity was tried according to the previously described method.

To prove the effect of activators, caseinolytic activity was also assayed in the presence of $12 \mathrm{mM}$ cysteine, and 1.5 and $5 \mathrm{mM}$ dithiotreitol.

\subsection{Isoelectric focusing (IEF) and zymogram}

IEF was carried out in a Mini IEF Cell (Model 111, Bio-Rad). The sample was precipitated with five volumes of cold acetone and redissolved in deionized water twice. The sample and pI markers (Sigma IEF MIX 3.6-9.3) were loaded onto 5\% polyacrylamide gel with a $\mathrm{pH}$ gradient in the range from 3 to 10 (Biolyte 3-10 carrier ampholytes, Bio-Rad, Hercules, CA), and the focusing of proteases present 
in crude extract was performed according to these conditions: $100 \mathrm{~V}$ for $15 \mathrm{~min}$, $200 \mathrm{~V}$ for the following $15 \mathrm{~min}$, and $450 \mathrm{~V}$ for the last $60 \mathrm{~min}$. One of the gels was fixed and stained with Coomassie Brilliant Blue R-250, while the other, unstained, was contacted for $20 \mathrm{~min}$ at $56{ }^{\circ} \mathrm{C}$ with an agarose gel imbibed in $1 \%$ casein solution, in order to detect the bands with proteolytic activity [14]. After incubation, the agarose gel was dehydrated and stained with Coomassie Brilliant Blue R-250.

\subsection{Endoesterolytic preference determination on synthetic substrates}

Enzymatic hydrolysis of $N$ - $\alpha$-carbobenzoxy- $p$-nitrophenyl esters of different amino acids was carried out in $0.1 \mathrm{M}$ Tris- $\mathrm{HCl}$ buffer ( $\mathrm{pH}$ 9.0) containing $2 \mathrm{mM}$ EDTA and $10 \mathrm{mM}$ cysteine at $45{ }^{\circ} \mathrm{C}$. To $50 \mu \mathrm{l}$ of crude extract solution, $50 \mu \mathrm{l}$ of $1 \mathrm{mM}$ substrate acetonitrile stock solution and $2.9 \mathrm{ml}$ of the mentioned buffer solution were added [15]. Absorbance was followed spectrophotometrically at $405 \mathrm{~nm}$ every $10 \mathrm{~s}$ for 2 min. The esterolytic activity was expressed using an arbitrary enzyme unit $\left(U_{\mathrm{cbz}}\right)$, defined as the amount of peptidase that released $1 \mu \mathrm{mol} / \mathrm{min}$ of $p$-nitrophenolate in the assay conditions. A standard curve of $p$-nitrophenol was performed to determine the micromoles produced during the reaction.

\subsection{Crude extract chromatographic profile}

Crude extract $(3.0 \mathrm{ml})$ was applied to a Pharmacia XK 16/40 column, packed with DEAE-Sepharose Fast Flow. The column was equilibrated with $55 \mathrm{mM}$

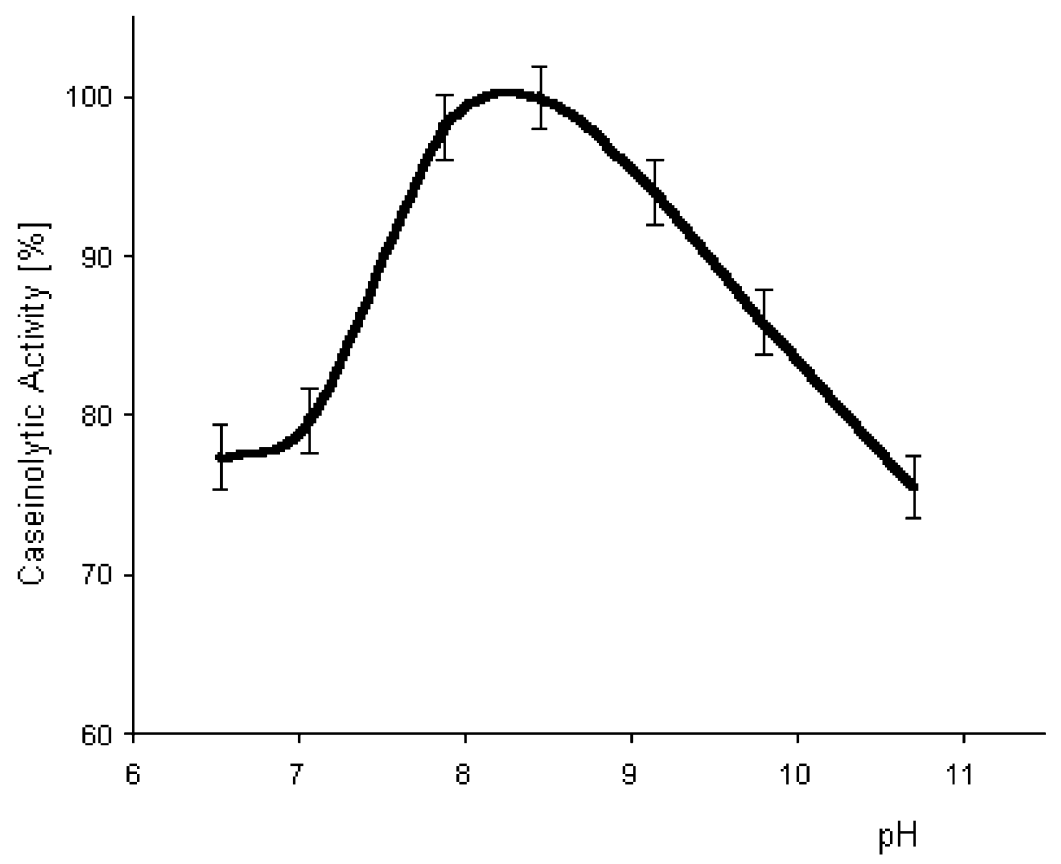

Fig. 1. Effect of $\mathrm{pH}$ on proteolytic activity of $F$. clausum latex crude enzymatic extract. 
phosphate buffer $\mathrm{pH} 7.5$, and the chromatography was developed in a FPLC equipment (Pharmacia) by washing with $17 \mathrm{ml}$ of the equilibrating buffer and the bound material eluted with a linear gradient of sodium chloride $(0-0.3 \mathrm{M})$ in the same buffer. The non-retained fraction was rechromatographied on SP-Sepharose Fast Flow equilibrated with citric-phosphate buffer $55 \mathrm{mM} \mathrm{pH} \mathrm{6.5,} \mathrm{and} \mathrm{resolved} \mathrm{by}$ washing the column with $22 \mathrm{ml}$ of the mentioned buffer and applying a $\mathrm{NaCl}$ gradient $(0-0.4 \mathrm{M})$ in the same buffer.

\subsection{Molecular mass determination by SDS-PAGE}

SDS-polyacrylamide gel electrophoresis with tricine cathodic buffer was carried out in $10 \%$ polyacrylamide gels [16]. Samples were loaded together with molecular weight markers. Potential was kept constant at $40 \mathrm{mV}$ for the stacking gel and at $150 \mathrm{mV}$ for the resolution gel. The gels were stained with Coomassie Brilliant Blue R-250 and scanned for the estimation of molecular masses of the proteolytic fractions eluted from both columns by using the Scion Image software [17].

\subsection{Caseinolytic activity detection in electrophoresis gels}

Electrophoresis in polyacrylamide gels (12\% acrylamide) was performed under non-denaturing conditions [18]. After the development of electrophoresis, SDS was

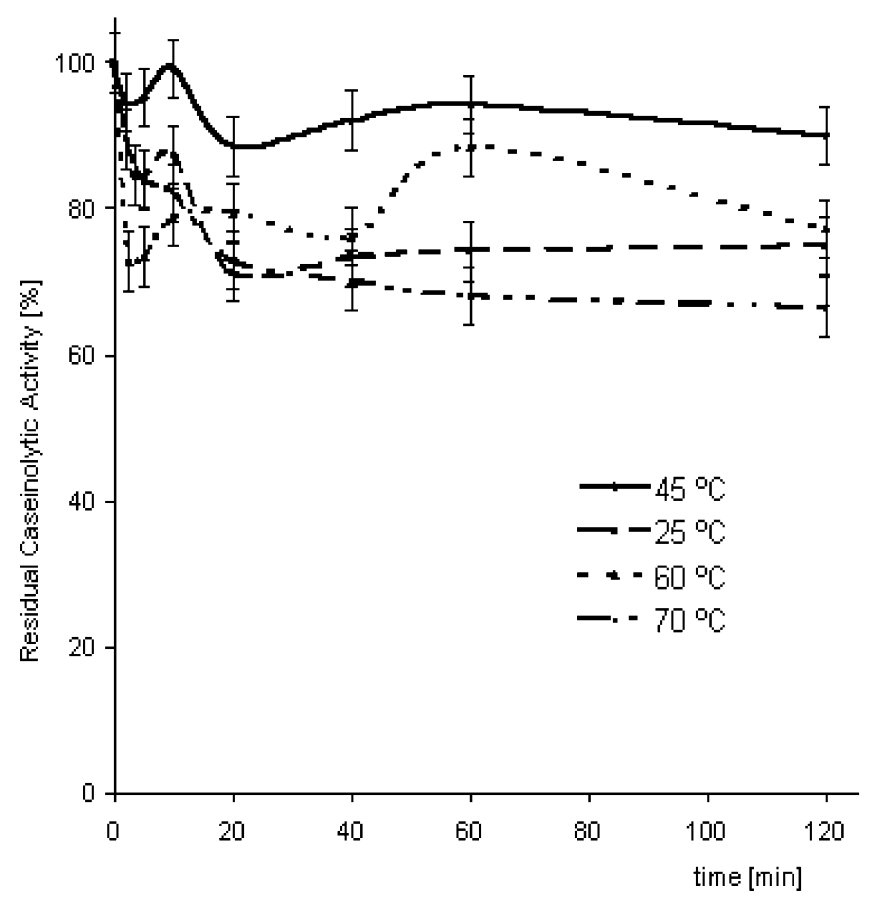

Fig. 2. Heat stability of $F$. clausum latex crude extract. 
removed by gently shaking the gels at room temperature for $30 \mathrm{~min}$ in Triton X$1002.5 \%$ in water and then soaked with deionized water three times during $10 \mathrm{~min}$ each. The resulting gels were incubated into $1 \%$ casein solution in buffer $0.1 \mathrm{M}$ Tris- $\mathrm{HCl} \mathrm{pH} 8$ for $30 \mathrm{~min}$ at $45{ }^{\circ} \mathrm{C}$. Proteolysis was stopped by staining with Coomassie Brilliant Blue R-250, after a brief water wash. Control electrophoresis was carried out under the same conditions, and simultaneously, was fixed and stained with silver to identify those bands with caseinolytic activity [19].

\section{Results and discussion}

\subsection{Proteolytic activity of crude extract}

Proteolytic activity presence was analyzed in the crude extract. The optimum $\mathrm{pH}$ range obtained was 8.0-10.0 (Fig. 1). The proteolytic extract showed a remarkable stability at different temperatures, including those as high as $60-70{ }^{\circ} \mathrm{C}$ (Fig. 2). Other crude extracts with proteolytic activity obtained from latices of Asclepiadaceae, such as Morrenia brachystephana [7] and M. odorata [20] showed a similar behaviour. Nevertheless, crude extract from $F$. clausum displayed an unusually high remaining activity at $70{ }^{\circ} \mathrm{C}$ (more than $60 \%$ after $2 \mathrm{~h}$ of incubation), whereas those belonging to the studied Morrenia genus were $45 \%$ for the former and $22 \%$ for the latter.

$0.1 \mathrm{mME}-64$

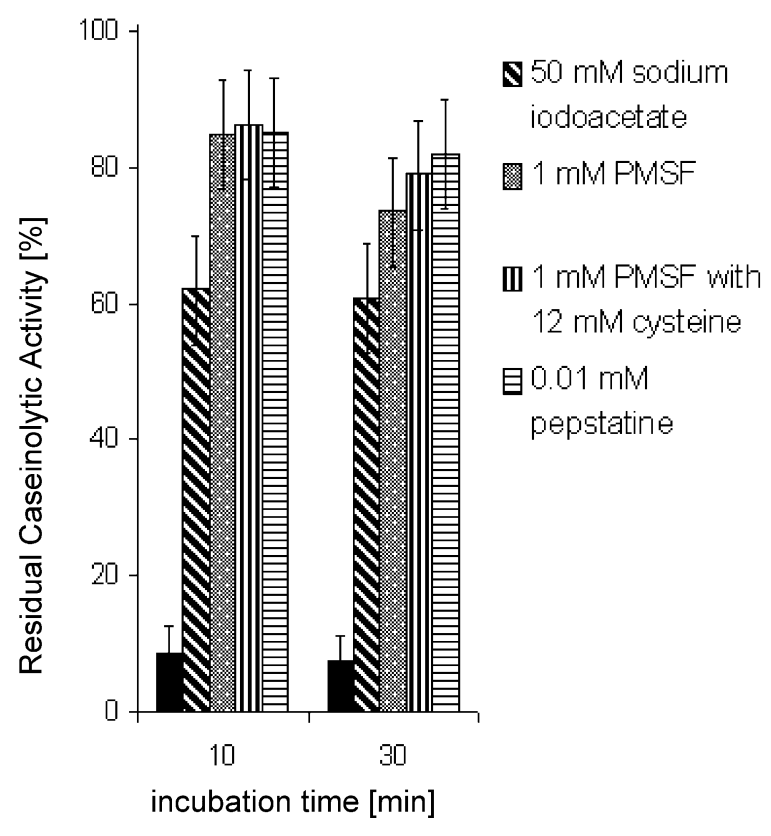

Fig. 3. Effect of different protease inhibitors on F. clausum latex crude extract activity. 


\subsection{Effect of inhibitors and activators}

Proteolytic activity of the crude extract almost disappeared after incubation for 10 and $30 \mathrm{~min}$ with $0.1 \mathrm{mM} \mathrm{E}-64$ (Fig. 3), an irreversible inhibitor for cysteine proteases belonging to the papain family, as well as it was enhanced by activators such as $12 \mathrm{mM}$ cysteine (1.5-fold) and dithiotreitol (1.2-fold for $1.5 \mathrm{mM}$ DTT and 1.5 -fold for $5 \mathrm{mM}$ DTT). Sodium iodoacetate provoked a decrease of $40 \%$ in the caseinolytic activity. A slight recovery of caseinolytic activity after incubating with cysteine, the sample inhibited by PMSF was observed, because of its reversible inhibitor nature in the case of cysteine proteinases. Pepstatin had little effect on activity. All these results suggested that the proteases present in latex of $F$. clausum belong to the cysteine group, as all the proteases already mentioned.

\subsection{Esterolytic activity}

Hydrolysis of several $N$ - $\alpha$-CBZ-amino acids $p$-nitrophenyl esters by crude extract revealed a major preference for the alanine (Ala) derivative, followed by those of asparagine (Asn) and tyrosine (Tyr), but in a very lower extent. The lowest preference was shown for the valine (Val), isoleucine (Ile) and proline (Pro)

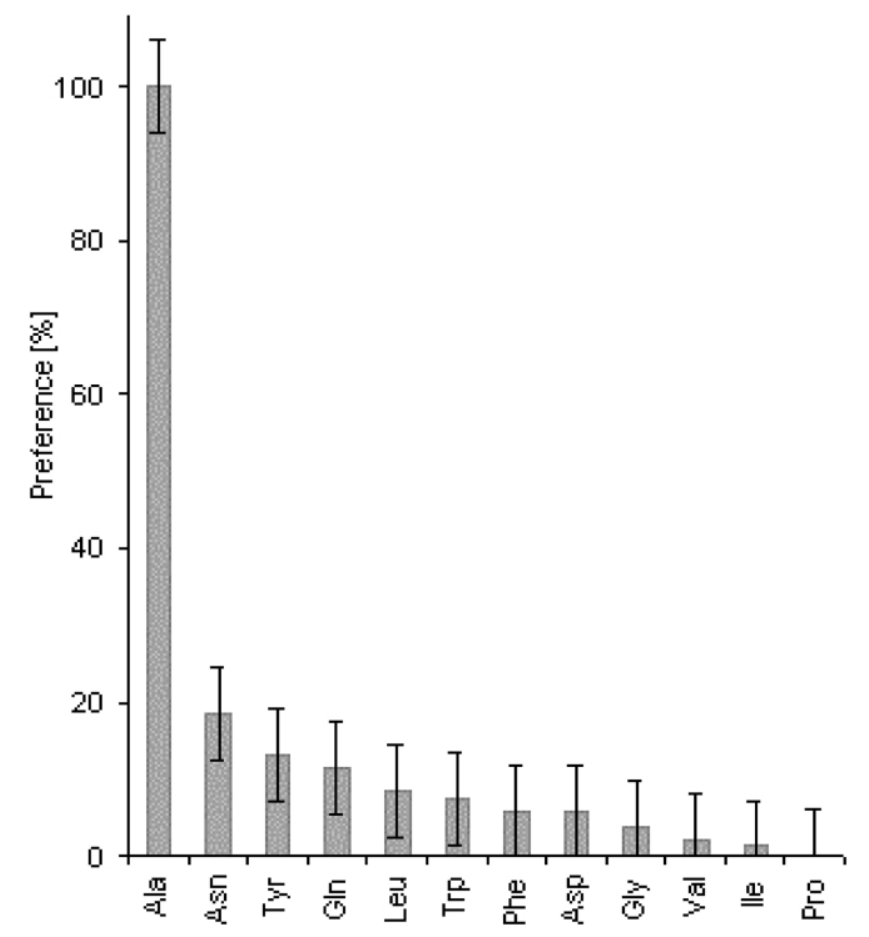

Fig. 4. Preference percentages of $F$. clausum latex crude extract on different $N$ - $\alpha$-CBZ-amino acids- $p$ nitrophenyl esters. 


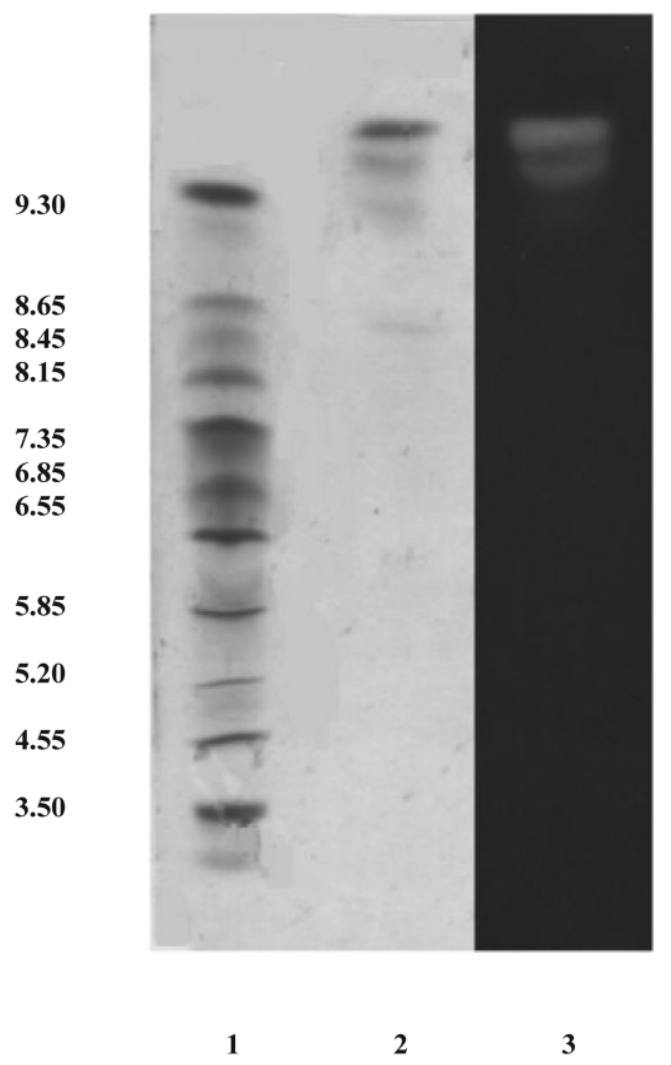

Fig. 5. IEF and zymogram. Lane 1: Sigma IEF MIX markers: Amyloglucosidase from Aspergillus niger, 3.6; Trypsin inhibitor from soybean, 4.6; $\beta$-Lactoglobulin A from bovine milk, 5.1; Carbonic anhidrase II from bovine erythrocytes, 5.9; Carbonic anhidrase I from human erythrocites, 6.6; Myoglobin from horse heart, 6.8,7.2; Lectin from Lens culinaris, 8.2, 8.6, 8.8; Trypsinogen from bovine pancreas, 9.3. Lane 2: F. clausum latex crude extract. Lane 3: corresponding zymogram to F. clausum latex crude extract.

derivatives (Fig. 4). The high affinity for the $N$ - $\alpha$-CBZ-Ala $p$-nitrophenyl ester is a common feature for the proteases studied in our laboratory [21-23]. The low affinities for the Val, Ile and Pro derivatives are in good agreement with those obtained for Araujia hortorum proteases [24].

\subsection{Chromatographic profile}

Since the pI of the proteolytic fractions was above 9.3 (Fig. 5), according to the results observed in the isoelectric focusing, an anion exchange was chosen to separate the proteins without endopeptidasic activity (Fig. 6a). The protease purified in this step was collected under the name of funastrain c I, in agreement with previous nomenclature recommendations $[25,26]$. As the main fraction showing 

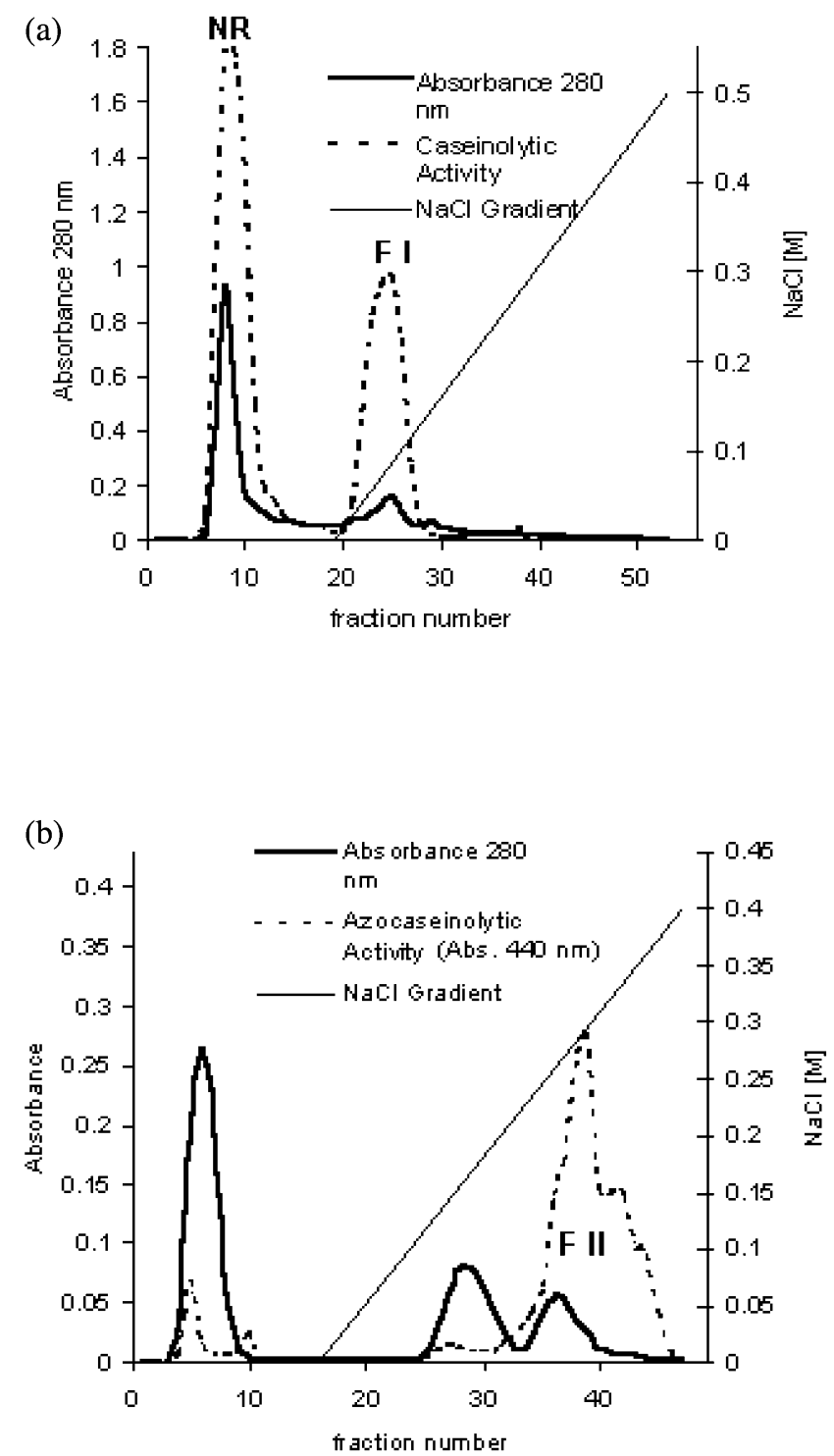

Fig. 6. (a) Anion exchange chromatography (DEAE-Sepharose Fast Flow Pharmacia XK 16/40 column, FPLC system). Elution buffer: $55 \mathrm{mM}$ phosphate $\mathrm{pH}$ 7.5. Gradient: sodium chloride 0-0.5 M. Wash flow rate: $0.75 \mathrm{ml} \mathrm{min}^{-1}$; gradient flow rate: $0.50 \mathrm{ml} \mathrm{min}^{-1}$. (b) Cation exchange recromatography of NR (non-retained fraction) on SP-Sepharose Fast Flow Pharmacia XK 16/40 column, FPLC system. Elution buffer: $55 \mathrm{mM}$ citric-phosphate $\mathrm{pH}$ 6.5. Gradient: sodium chloride $0-0.4 \mathrm{M}$. Wash flow rate: $0.75 \mathrm{ml} \mathrm{min}{ }^{-1}$; gradient flow rate: $0.50 \mathrm{ml} \mathrm{min}{ }^{-1}$. 
Table 1

Properties of F. clausum latex crude extract, funastrain c I and funastrain c II

\begin{tabular}{|c|c|c|c|c|c|c|c|c|c|}
\hline Sample & $\begin{array}{l}\text { Volume } \\
(\mathrm{ml})\end{array}$ & $\begin{array}{l}\text { Protein } \\
\text { content } \\
(\mathrm{mg} / \mathrm{ml})\end{array}$ & $\begin{array}{l}\text { Carbohydrate } \\
\text { content } \\
(\mathrm{mg} / \mathrm{ml})\end{array}$ & $\begin{array}{l}\text { Total proteins } \\
(\mathrm{mg})\end{array}$ & $\mathrm{UCAS} / \mathrm{ml}$ & $\begin{array}{l}\text { Total } \\
\text { UCAS }\end{array}$ & $\begin{array}{l}\text { Specific activity } \\
\text { (UCAS/mg) }\end{array}$ & $\begin{array}{l}\text { Purification } \\
\text { (fold) }\end{array}$ & Yield (\%) \\
\hline Crude extract & 3.0 & 0.30 & 0.18 & 0.9 & 0.70 & 2.1 & 2.4 & - & - \\
\hline $\mathrm{NR}^{\mathrm{a}}$ & 7.0 & 0.07 & - & 0.5 & 0.26 & 1.4 & 3.5 & 1.5 & 88.5 \\
\hline Funastrain c I & 6.5 & 0.03 & - & 0.2 & 0.14 & 0.9 & 4.6 & 2 & 45 \\
\hline Funastrain c II & 12.5 & 0.02 & - & 0.3 & 0.01 & 0.2 & 0.6 & 0.3 & 8.5 \\
\hline
\end{tabular}

${ }^{a}$ Non-retained fraction eluted from the anion exchange chromatography. 


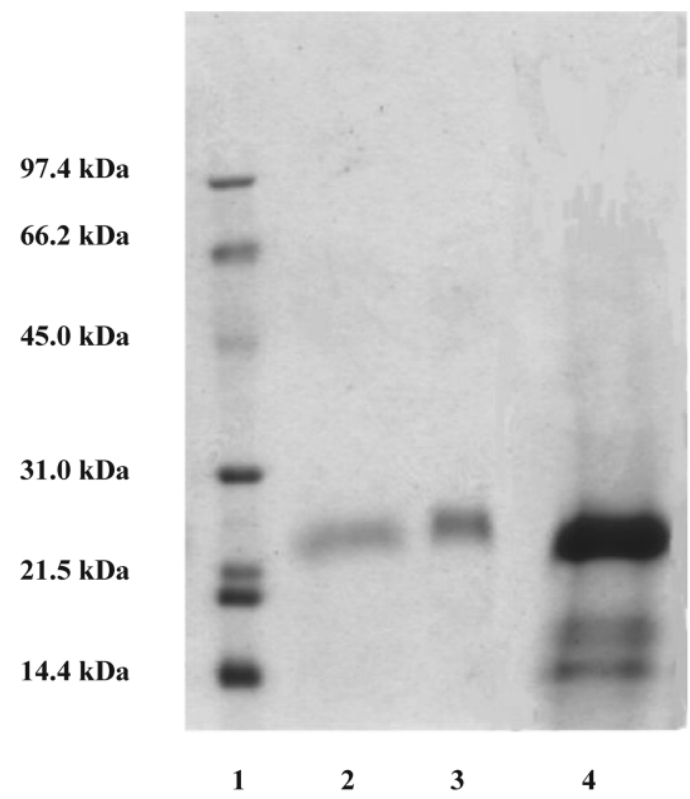

Fig. 7. SDS-PAGE. Lane 1: Molecular weight Bio Rad markers: Phosphorylase b, 97.4 kDa; Serum albumin, $66.2 \mathrm{kDa}$; Ovalbumin, $45.0 \mathrm{kDa}$; Carbonic anhidrase, $31.0 \mathrm{kDa}$; Trypsin inhibitor, $21.5 \mathrm{kDa}$; and Lysozyme, $14.4 \mathrm{kDa}$. Lane 2: Funastrain c I. Lane 3: funastrain c II. Lane 4: F. clausum latex crude extract.

caseinolytic activity was found in the non-retained peak, cation chromatography was applied to this fraction (Fig. 6b), allowing the separation of a second protease (funastrain c II). As can be seen in the purification table (Table 1), funastrain c I comprised $45 \%$ of the whole proteolytic activity, as its purification factor was twofold. The specific activity of funastrain c II was much lower than the one expected from the results obtained for the non-retained fraction: its poor yield $(8.5 \%)$ and the extreme low purification degree $(0.2)$ would indicate that most biological activity of funastrain $\mathrm{c}$ II was lost during the purification process, and a new strategy to purify this fraction should be performed.

\subsection{Electrophoresis}

SDS-PAGE electrophoresis patterns of the crude extract and the purified fractions are shown in Fig. 7. Relative molecular masses of the two proteases preliminary purified were 24.4 for funastrain c I and $24.0 \mathrm{kDa}$ for funastrain c II, in concordance with those of the purified proteases from other species belonging to the Asclepiadaceae, as Asclepias glaucescens [25,26], A. syriaca [27], Calotropis gigantea [2830], M. brachystephana [7], M. odorata [20], Araujia hortorum [31,32] and A. fruticosa [23], all ranging from 23 to $27 \mathrm{kDa}$. Native electrophoresis (Fig. 8) and IEF zymogram (Fig. 5) confirmed the peptidasic activity of those fractions. 


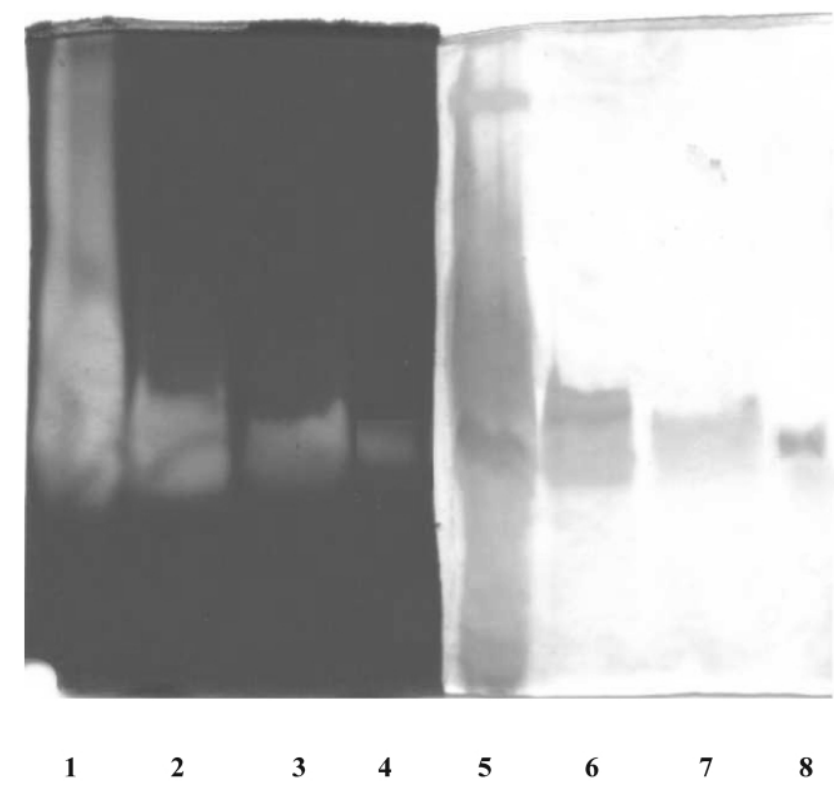

Fig. 8. Native electrophoresis and zymogram. Zymogram: in situ caseinolytic activity. Lane 1: F. clausum latex crude extract. Lane 2: Anion exchange non-retained fraction. Lane 3: Funastrain c I. Lane 4: Funastrain c II. Control native electrophoresis. Lane 5: F. clausum latex crude extract. Lane 6: Anion exchange non-retained fraction. Lane 7: Funastrain c I. Lane 8: Funastrain c II.

\section{Acknowledgments}

The authors acknowledge Dr Adriana Cortadi for plant material collection. S.R. Morcelle was awarded fellowship by CONICET, and N.O. Caffini belongs to CIC Researcher Career. The present work was supported by grants from ANPCyT and CONICET.

\section{References}

[1] Lynn KR, Clevette-Radford NA. Phytochemistry 1987;26:939.

[2] Vierstra R. Plant Mol Biol 1996;32:372.

[3] Uhlig H. Industrial enzymes and their applications. John Wiley and Sons, 1998.

[4] Kelly G. Altern Med Rev 1996;1:243.

[5] http://www.ars-grin.gov/duke/dictionary/tico/f.html 2003.

[6] Burkart A. Colección Científica del INTA. Tomo VI-V. Buenos Aires, 1979.

[7] Arribére MC, Cortadi AA, Gattuso MA, Bettiol MP, Priolo NS, Caffini NO. Phytochem Anal 1998;9:267.

[8] Priolo NS, López LMI, Arribére MC, Natalucci CL, Caffini NO. Acta Alimentaria 1991;20:189.

[9] López LMI. Isolation, purification and characterization of proteases from latex of Maclura pomifera (Raf.) Schneid. (Moraceae). Ph.D. Thesis, Facultad de Ciencias Exactas, Universidad Nacional de La Plata, Argentina, 1995.

[10] Bradford MM. Anal Biochem 1976;72:248. 
[11] Dubois M, Gilles KA, Hamilton JK, Rebers PA, Smith F. Anal Chem 1956;28:350.

[12] Good NE, Izawa S. Meth Enzymol (Part B) 1972;24:53.

[13] Salvesen G, Nagase H. In: Beynon RJ, Bond JS, editors. Proteolytic enzymes, a practical approach. Oxford: IRL Press, 1989.

[14] Westergaard JL, Hackbarth C, Treuhaft MW, Roberts RC. J Immunol Meth 1980;34:167.

[15] Silverstein RM. Analyt Biochem 1974;62:478.

[16] Shägger H, von Jagow G. Analyt Biochem 1987;166:368.

[17] Scion Corporation. 82 Worman's Mill Court, Suite H. Web site: http: //www.scioncorp.com.

[18] Vázquez Peyronel D, Cantera AMB. Electrophoresis 1995;16:1894.

[19] Blum H, Beier H, Gross HJ. Electrophoresis 1987;8:93.

[20] Arribére MC, Vairo Cavalli SE, Priolo NS, Caffini NO, Gattuso M, Cortadi AA. Acta Horticulturae 1999;501:259.

[21] Vairo Cavalli S, Arribére MC, Cortadi A, Caffini NO, Priolo NS. J Protein Chem 2003;22:15.

[22] Vairo Cavalli S, Cortadi A, Arribére MC, Conforti P, Caffini NO, Priolo NS. Biol Chem 2001;382:879.

[23] Trejo SA, López LMI, Cimino CV, Caffini NO, Natalucci CL. J Protein Chem 2001;20:445.

[24] Priolo NS, Arribére MC, Caffini NO, Barberis SE, Nieto Vázquez R, Luco JM. J Mol Catal B: Enzym 2001;15:177.

[25] Barragán BE, Cruz MT, del Castillo LM, Castañeda-Agulló M. Rev Latinoamer Quím 1985;16:117.

[26] Tablero M, Arreguín R, Arreguín B, Soriano M, Sánchez RI, Rodríguez Romero A, et al. Plant Sci 1991;74:7.

[27] Brockbank WJ, Lynn KR. Biochem Biophys Acta 1979;578:113.

[28] Abraham KI, Joshi PN. Biochem Biophys Acta 1979a;568:111.

[29] Abraham KI, Joshi PN. Biochem Biophys Acta 1979b;568:120.

[30] Pal G, Sinha NK. Arch Biochem Biophys 1980;202:321.

[31] Priolo NS, Morcelle del Valle S, Arribére MC, López LMI, Caffini NO. J Protein Chem 2000;19:39.

[32] Obregón WD, Arribére MC, Morcelle del Valle S, Liggieri C, Caffini NO, Priolo NS. J Protein Chem 2001;20:17. 